Article

\title{
Inhibitory Effect of Sauchinone on UDP-Glucuronosyltransferase (UGT) 2B7 Activity
}

\author{
Byoung Hoon You, Eun Chae Gong and Young Hee Choi * \\ College of Pharmacy and Intergrated Research Institute for Drug Development, Dongguk University-Seoul, \\ 32 Dongguk-lo, Ilsandong-gu, Goyang, Gyonggi-do 10326, Korea; hoon4131@nate.com (B.H.Y.); \\ dmsco3901@hanmail.net (E.C.G.) \\ * Correspondence: choiyh@dongguk.edu; Tel.: +82-31-961-5212
}

Received: 4 January 2018; Accepted: 7 February 2018; Published: 9 February 2018

\begin{abstract}
Herb-drug interaction (HDI) limits clinical application of herbs and drugs, and inhibition of herbs towards uridine diphosphate (UDP)-glucuronosyltransferases (UGTs) has gained attention as one of the important reasons to cause HDIs. Sauchinone, an active lignan isolated from aerial parts of Saururus chinensis (Saururacease), possesses anti-oxidant, anti-inflammatory, and anti-viral activities. In pharmacokinetics of sauchinone, sauchinone is highly distributed to the liver, forming extensive metabolites of sauchinone via UGTs in the liver. Thus, we investigated whether sauchinone inhibited UGTs to explore potential of sauchinone-drug interactions. In human liver microsomes (HLMs), sauchinone inhibited activities of UGT1A1, 1A3, 1A6, and 2B7 with $\mathrm{IC}_{50}$ values of 8.83, 43.9, 0.758 , and $0.279 \mu \mathrm{M}$, respectively. Sauchinone also noncompetitively inhibited UGT1A6 and 2B7 with $K_{\mathrm{i}}$ values of 1.08 and $0.524 \mu \mathrm{M}$, respectively. In in vivo interaction study using mice, sauchinone inhibited UGT2B7-mediated zidovudine metabolism, resulting in increased systemic exposure of zidovudine when sauchinone and zidovudine were co-administered together. Our results indicated that there is potential HDI between sauchinone and drugs undergoing UGT2B7-mediated metabolism, possibly contributing to the safe use of sauchinone and drug combinations.
\end{abstract}

Keywords: sauchinone; Saururus chinensis; UGT2B7; inhibition; drug interaction

\section{Introduction}

Herb-drug combinations have been steadily increased and encouraged as main medical treatments by the World Health Organization [1,2]. Since herb-drug interactions (HDIs) can limit clinical application of herbs and drugs, inhibition of herbs toward uridine diphosphate (UDP)-glucuronosyltransferases (UGTs) has received attention in association with alternations of drug efficacy or toxicity [3-5].

UGTs are phase II metabolic enzymes that predominantly catalyze glucuronidation of xenobiotics, including approximately $35 \%$ of drugs and consequently, facilitating elimination of glucuronidated metabolites through bile and urine [6,7]. Glucuronidation clears drugs because glucuronidated metabolites have more polarity and water solubility. It also detoxifies drugs because glucuronidated metabolites possess less activity or toxicity than their parent forms [8]. Many cases of UGT inhibition-mediated drug interactions have been reported [5,7] including UGT1A1 inhibition by psoralidin that causes irinotecan' toxicity [9], UGT1A3 inhibition by gemfibrozil that enhances susceptibility of statins [10], UGT1A6 inhibition by silybin that attenuates fenofibrate-induced UGT1A6 [11], UGT1A6 inhibition by phenobarbital and phenytoin that causes hepatotoxicity of acetamoniphen [12,13], UGT1A9 inhibition by mefenamic acid that changes exposure of dapagliflozin's metabolite [14], and UGT2B7 inhibition by valproic acid that changes efficacy and toxicity of zidovudine [15]. Regulatory agencies have recognized the importance of UGT-mediated drug 
interactions in drug discovery research and patients' safety $[2,16,17]$. Moreover, the U.S. FDA strongly recommends the evaluation of UGT-mediated interactions in HDIs [3,16-18].

Saururus chinensis Hort. ex Loudon (Saururaceae), commonly known as Chinese lizard's tail or Sam-baek-cho in Korea, is a plant with a long history of medical use. It has been used to treat hepatitis in Korea $[19,20]$ and edema, pneumonia, jaundice, gonorrhea and inflammatory disease in North Asia [21]. Sauchinone is a biologically active lignan isolated from aerial parts of $S$. chinensis, showing anti-inflammatory and anti-viral activities [22,23]. In pharmacokinetic studies, sauchinone is highly distributed to the liver where UGTs can extensively catalyze sauchinone metabolism [24,25]. Thus, there might be potential of sauchinone-drug interaction through UGT-mediated metabolism. However, currently there is no information regarding inhibition of UGTs by sauchinone. Therefore, the objective of this study was to determine the inhibitory effect of sauchinone on UGT1A1, 1A3, 1A4, 1A6, 1A9, and 2B7 activities. Inhibition kinetics of sauchinone was then investigated in in vitro using human liver microsomes (HLMs). Pharmacokinetic interaction of sauchinone and zidovudine, a substrate of UGT2B7, was also evaluated in vivo using mice.

\section{Results}

\subsection{Inhibitory Effects of Sauchinone on UGT Activities}

The inhibitory effects of sauchinone on UGT1A1, 1A3, 1A4, 1A6, 1A9, and 2B7 were shown in Figure 1 and their $\mathrm{IC}_{50}$ values are listed in Table 1 . When sauchinone concentrations were increased to $200 \mu \mathrm{M}, \mathrm{IC}_{50}$ values of UGT1A1-catalyzed $\beta$-estradiol, UGT1A3-catalyzed CDCA, 1A6-catalyzed serotonin, and 2B7-catalyzed zidovudine $(8.83,43.9,0.758$, and $0.279 \mu \mathrm{M}$, respectively) were lower than those of well-known inhibitors such as chrysin, lithocholic acid, 1-naphthol, and efavirenz $(28.3,69.8$, 35.2 , and $75.4 \mu \mathrm{M}$ respectively), indicating that sauchione inhibited metabolic activities of UGT1A1, 1A3, 1A6, and 2B7 in HLM. Sauchinone also showed negligible inhibitory effect on UGT1A4 and 1A9 activities under our study conditions.
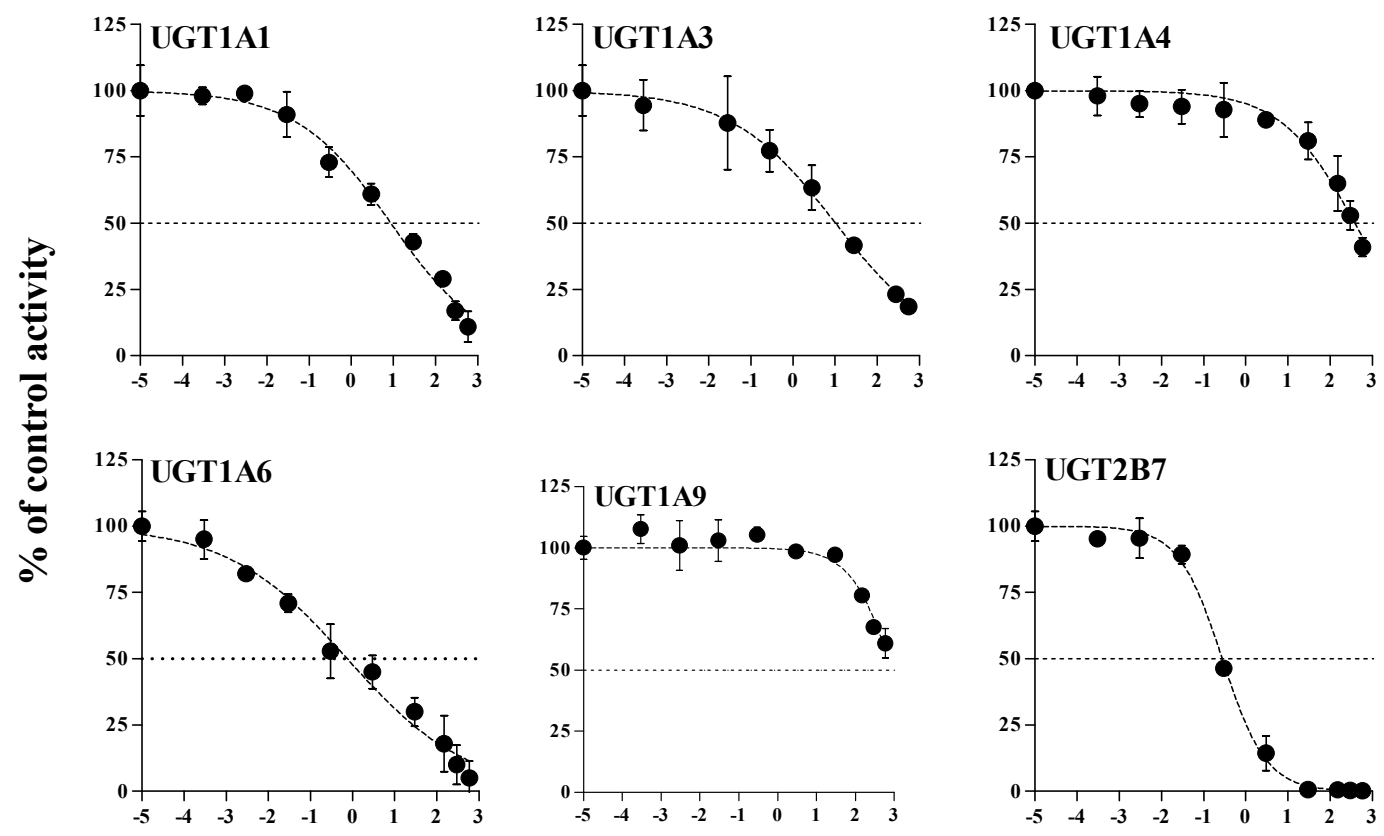

Sauchinone $(\log \mu \mathrm{M})$

Figure 1. $\mathrm{IC}_{50}$ curves for the direct inhibition of UGT1A1, UGT1A3, UGT1A4, UGT1A6, UGT1A9, and UGT2B7 in HLMs. The ' $\bullet$ ' represents the remaining percentage of UGT-mediated metabolic activity with sauchinone as an inhibitor versus control (without sauchinone). ( $n=3$ for each group). 
Table 1. $\mathrm{IC}_{50}(\mu \mathrm{M})$ values of sauchinone ( $n=3$ for each UGT isoform) and well-known inhibitors $(n=1$ for each UGT isoform) for inhibition of various UGTs in human liver microsomes. Data were expressed as the mean values. The minimum and maximum values of $\mathrm{IC}_{50}$ were expressed in the parentheses.

\begin{tabular}{cccc}
\hline UGTs & Sauchinone & \multicolumn{2}{c}{ Well-Known Inhibitor } \\
\hline UGT1A1 & $8.83(5.40-14.5)$ & Chrysin & 28.3 \\
UGT1A3 & $43.9(18.9-102)$ & Lithocholic acid & 69.8 \\
UGT1A4 & $391(253-603)$ & Hecogenin & 3.99 \\
UGT1A6 & $0.758(0.383-1.50)$ & 1-Naphthol & 35.2 \\
UGT1A9 & $919(517-1632)$ & Niflumic acid & 0.755 \\
UGT2B7 & $0.279(0.224-0.347)$ & Efavirenz & 75.4 \\
\hline
\end{tabular}

\section{2. $K_{i}$ of Sauchinone on UGT1A6 and 2B7-Mediated Glucuronidation Activities}

Based on estimated $\mathrm{IC}_{50}$ values of sauchinone, enzyme kinetic assays of sauchinone on inhibition of UGT1A6 and 2B7 activities were conducted. Various concentrations of sauchinone were used and $K_{\mathrm{i}}$ values of sauchinone for UGT1A6 and 2B7 were estimated. Figure 2A,B showed the activities of UGT1A6-mediated serotonin glucuronidation and UGT2B7-mediated zidovudine glucuronidation with and without sauchinone as an inhibitor using nonlinear regression analysis. In Figure $2 \mathrm{~A}$, the maximum rate of metabolic activity $\left(\mathrm{V}_{\max }\right)$ and Michaelis-Menten constant $\left(\mathrm{K}_{\mathrm{m}}\right.$, the substrate concentration at which the reaction rate is half of $V_{\max }$ ) for UGT1A6-mediated serotonin glucuronidation without sauchinone were $174 \mu \mathrm{M} / \mathrm{min} / \mathrm{mg}$ protein and $126 \mu \mathrm{M}$, respectively. As increasing sauchinone (as an inhibitor) concentrations from 0 to $50 \mu \mathrm{M}, \mathrm{V}_{\max }$ tended to decrease from 174 to $6.36 \mu \mathrm{M} / \mathrm{min} / \mathrm{mg}$ protein, but $\mathrm{K}_{\mathrm{m}}$ represented in the ranges of 103-126 $\mu \mathrm{M}$ for UGT1A6-mediated serotonin glucuronidation. Also in Figure $2 \mathrm{~B}, \mathrm{~V}_{\max }$ and $\mathrm{K}_{\mathrm{m}}$ for UGT2B7-mediated zidovudine glucuronidation without sauchinone were $31.5 \mu \mathrm{M} / \mathrm{min} / \mathrm{mg}$ protein and $85 \mu \mathrm{M}$, respectively. With increasing sauchinone concentrations (as an inhibitor) from 0 to $50 \mu \mathrm{M}, \mathrm{V}_{\max }$ tended to decrease from 31.5 to $0.495 \mu \mathrm{M} / \mathrm{min} / \mathrm{mg}$ protein, but $\mathrm{K}_{\mathrm{m}}$ represented in the ranges of 70.2-85.0 $\mu \mathrm{M}$ for UGT2B7-mediated zidovudine glucuronidation.

As shown in Figure 2C,D, all Dixon plots for the inhibition of sauchinone on UGT1A6 and 2B7 fitted well with the noncompetitive inhibition mode in visual inspection [25], suggesting that sauchinone could noncompetitively inhibit UGT1A6 and 2B7. $K_{\mathrm{i}}$ values of sauchinone for UGT1A6 and $2 \mathrm{~B} 7$ were $1.08(0.811-1.37) \mu \mathrm{M}$ and $0.524(0.442-0.610) \mu \mathrm{M}$, respectively.

\subsection{Inhibitory Effects of Sauchinone on Ugt Activities Using Mice Liver Microsomes (MLMs)}

The inhibitory effects of sauchinone on Ugt1a1, 1a3, 1a6, 1a9, and $2 \mathrm{~b} 7$ were shown in Figure 3. When sauchinone concentrations were adjusted until $200 \mu \mathrm{M}, \mathrm{IC}_{50}$ values of Ugt1a1-catalyzed $\beta$-estradiol, Ugt1a3-catalyzed CDCA, Ugt1a6-catalyzed serotonin, Ugt1a9-catalyzed propofol, and Ugt2b7-catalyzed zidovudine $(152,79.9,29.8$, and $23.0 \mu \mathrm{M}$, respectively) in MLM. Also, sauchinone showed negligible inhibitory effects on Ugt1a6 in our conditions.

(A) UGT1A6

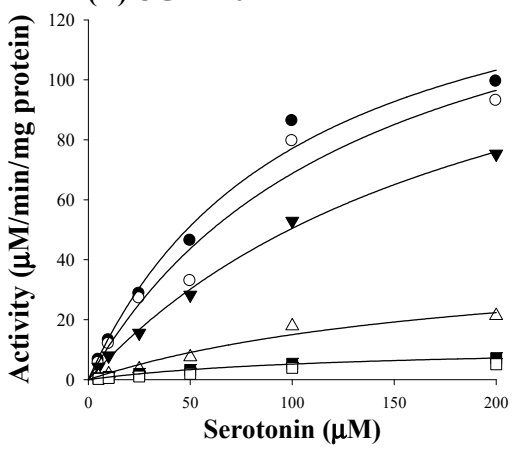

(B) UGT2B7

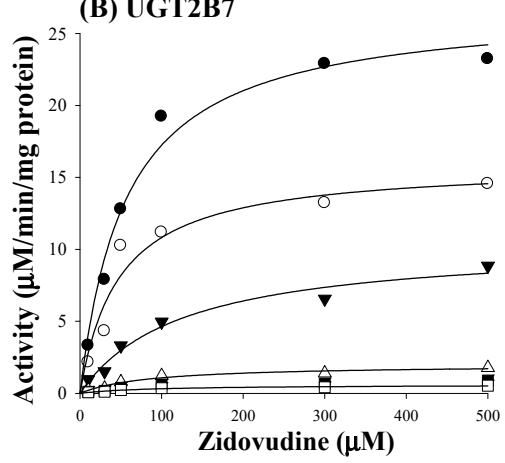

Figure 2. Cont. 
(C) UGT1A6

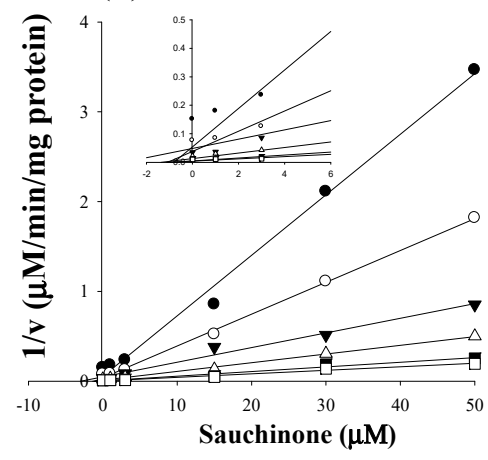

(D) UGT2B7

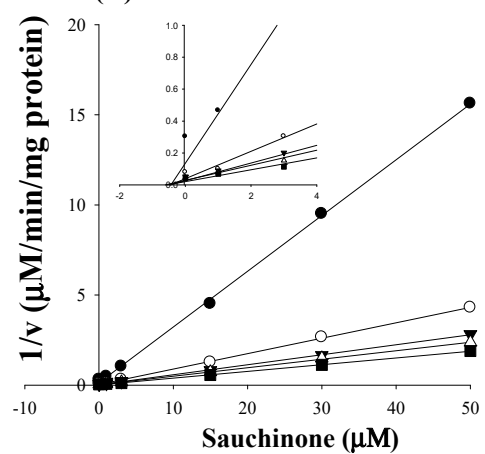

Figure 2. Inhibition of UGT1A6 and 2B7 by sauchinone. (A) The plot for velocities of UGT1A6-mediated serotonin glucuronidation versus serotonin concentrations depending on sauchinone concentrations. The following symbols $(\bullet, \circ, \mathbf{\nabla}, \triangle, \mathbf{\bullet}, \square)$ represent sauchinonne (as an inhibitor) concentrations of 0 , 1, 3, 15, 30, and $50 \mu \mathrm{M}$, respectively; (B) The plot for velocities of UGT2B7-mediated zidovudine glucuronidation versus zidovudine concentrations depending on sauchinone concentrations. The following symbols $(\bullet, \circ, \mathbf{\nabla}, \triangle, \mathbf{\bullet}, \square)$ represent sauchinonne (as an inhibitor) concentrations of $0,1,3,15,30$, and $50 \mu \mathrm{M}$, respectively; (C) Dixon plot of inhibitory effect of sauchinone on UGT1A6-mediated serotonin glucuronidation activity. The following symbols $(\bullet, \circ, \mathbf{\nabla}, \Delta, \mathbf{\bullet ,}$, ) represent sauchinonne (as an inhibitor) concentrations of $0,1,3,15,30$, and $50 \mu \mathrm{M}$, respectively; (D) Dixon plot of inhibitory effect of sauchinone on UGT2B7-mediated zidovudine glucuronidation activity. The following symbols $(\bullet, \circ, \mathbf{v}, \Delta, \mathbf{\bullet}, \square)$ represent sauchinonne (as an inhibitor) concentrations of $0,1,3$, 15,30 , and $50 \mu \mathrm{M}$, respectively.
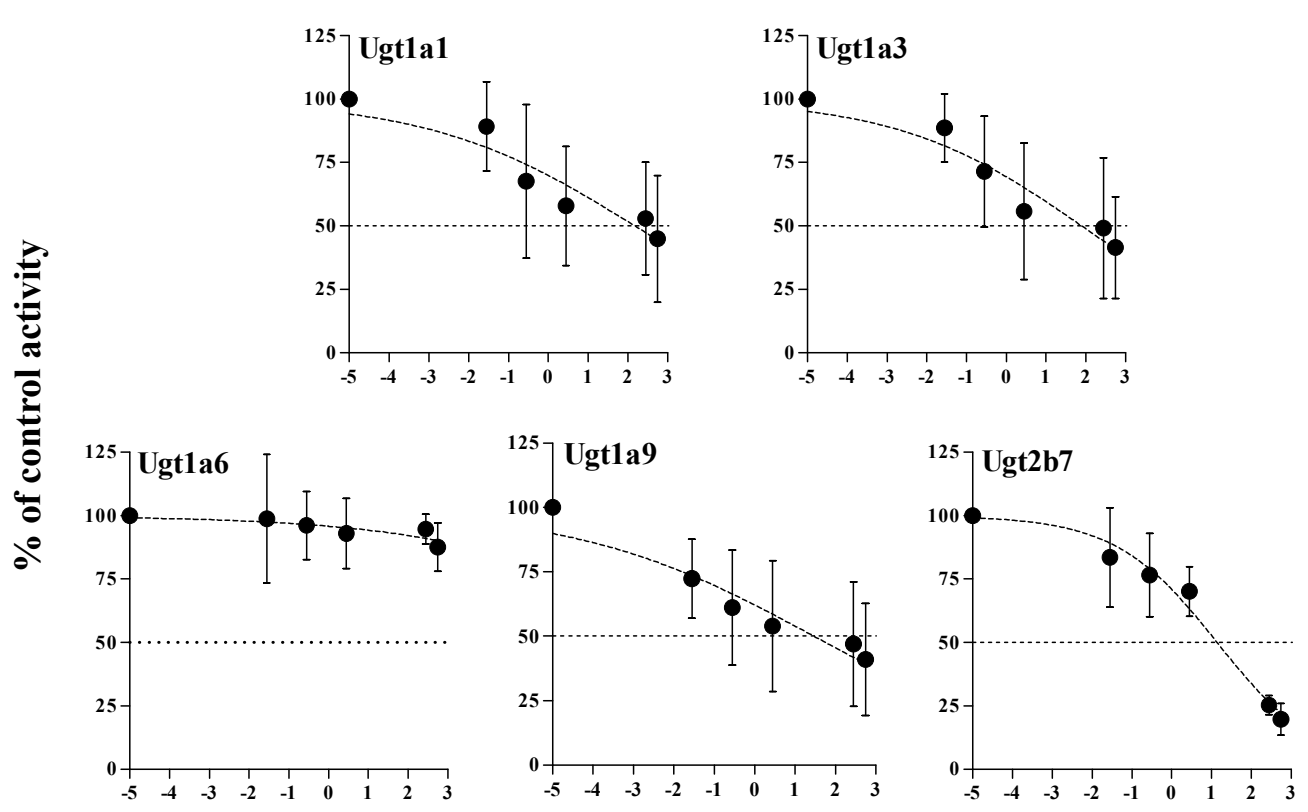

Sauchinone $(\log \mu \mathrm{M})$

Figure 3. $\mathrm{IC}_{50}$ curves for the direct inhibition of Ugt1a1, Ugt1a3, Ugt1a6, Ugt1a9, and Ugt2b7 in MLM. The ' $\bullet$ ' represents the remaining percentage of UGT-mediated metabolic activity with sauchinone as an inhibitor versus control (without sauchinone). ( $n=3$ for each group).

\subsection{Pharmacokinetic Study of Zidovudine with or without Sauchinone}

After administration of zidovudine together with sauchinone to mice, mean arterial plasma concentration-time profiles of zidovudine were obtained. Results are shown in Figure 4 and their 
relevant pharmacokinetic parameters are listed in Table 2. $\mathrm{AUC}_{480 \mathrm{~min}} \mathrm{CL}$, and $\mathrm{CL}_{\mathrm{NR}}$ of zidovudine with sauchinone were increased by $53.1 \%$, and decreased by $29.3 \%$ and $29.6 \%$, respectively, compared to those without sauchinone, indicating that sauchinone inhibited the metabolism of zidovudine via Ugt2b7.

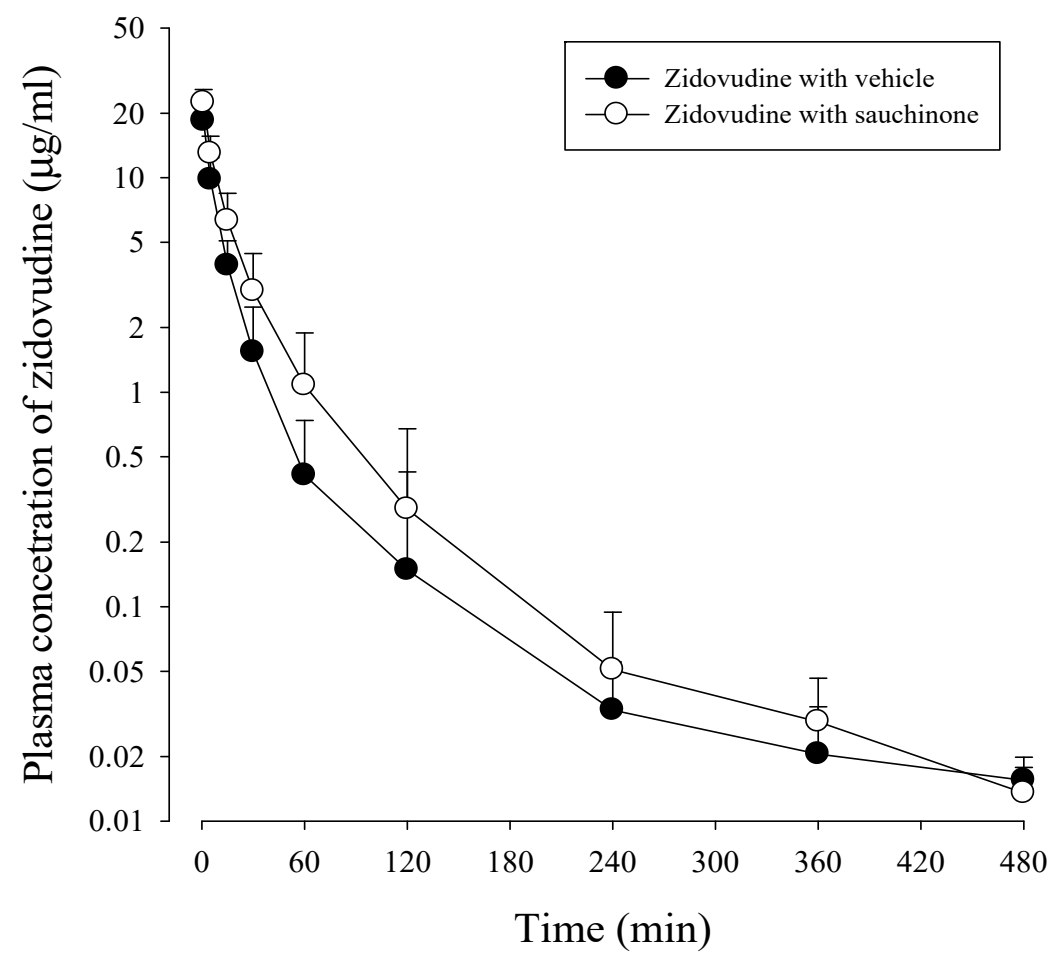

Figure 4. Plasma concentrations of zidovudine after intravenous administration of $15 \mathrm{mg} / \mathrm{kg}$ zidovudine with $(\circ: n=11)$ and without $(\bullet: n=11)$ oral administration of $100 \mathrm{mg} / \mathrm{kg}$ sauchinone.

Table 2. Means ( \pm standard deviations) of pharmacokinetic parameters of zidovudine after intravenous administration of $15 \mathrm{mg} / \mathrm{kg}$ zidovudine with or without oral administration of $100 \mathrm{mg} / \mathrm{kg}$ sauchinone ( $n=11$ for each group).

\begin{tabular}{ccc}
\hline Parameters & With Vehicle & With Sauchinone \\
\hline Body weight $(\mathrm{g})$ & $30.6 \pm 3.74$ & $31.7 \pm 3.37$ \\
$\mathrm{AUC}_{480 \mathrm{~min}}(\mu \mathrm{g} \mathrm{min} / \mathrm{mL})$ & $227 \pm 61.9$ & $344 \pm 142^{\mathrm{a}}$ \\
$\mathrm{AUC}(\mu \mathrm{g} \mathrm{min} / \mathrm{mL})$ & $228 \pm 60.8$ & $349 \pm 140^{\mathrm{a}}$ \\
$\mathrm{t}_{1 / 2}(\mathrm{~min})$ & $207 \pm 133$ & $178 \pm 93.1$ \\
$\mathrm{CL}(\mathrm{mL} / \mathrm{min} / \mathrm{kg})$ & $68.7 \pm 18.7$ & $48.6 \pm 16.1^{\mathrm{a}}$ \\
$\mathrm{CL}_{\mathrm{R}}(\mathrm{mL} / \mathrm{min} / \mathrm{kg})$ & $34.0 \pm 11.2$ & $24.0 \pm 8.02^{\mathrm{a}}$ \\
$\mathrm{CL}_{\mathrm{NR}}(\mathrm{mL} / \mathrm{min} / \mathrm{kg})$ & $34.8 \pm 10.5$ & $24.5 \pm 9.31^{\mathrm{a}}$ \\
$\mathrm{MRT}(\mathrm{min})$ & $55.8 \pm 28.2$ & $43.5 \pm 16.2$ \\
$\mathrm{Vss}(\mathrm{mL} / \mathrm{kg})$ & $3307 \pm 1670$ & $2105 \pm 1229$ \\
$\mathrm{Ae}_{0-24 \mathrm{~h}}(\%$ of dose $)$ & $50.3 \pm 8.01$ & $50.2 \pm 8.41$ \\
$\mathrm{GI}_{24} \mathrm{~h}(\%$ of dose $)$ & $0.672 \pm 0.999$ & $0.321 \pm 0.646$ \\
\hline a Significantly different $(p<0.05)$ from with vehicle.
\end{tabular}

$\mathrm{AUC}_{480 \mathrm{~min}}$, the area under the plasma concentration-time curve from time zero to last sampling time, $480 \mathrm{~min}$; AUC, the area under the plasma concentration-time curve from time zero to infinity; $\mathrm{t}_{1 / 2}$, terminal half-life; $\mathrm{CL}$, total body clearance; $\mathrm{CL}_{\mathrm{R}}$, renal clearance; $\mathrm{CL}_{\mathrm{NR}}$, non-renal clearance, $\mathrm{MRT}$, mean residence time; Vss, the apparent volume of distribution, $\mathrm{Ae}_{0-24} \mathrm{~h}$, percentage of zidovudine excreted into urine for $24 \mathrm{~h}, \mathrm{GI}_{24} \mathrm{~h}$, percentage of zidovudine remaining or excreted in $\mathrm{GI}$ at $24 \mathrm{~h}$. 


\section{Discussion}

Inhibition of drug-metabolic enzymes in drug combination therapies is considered an important origin of adverse effects. It can lead to withdrawal of several approved drugs from the markets, causing clinical problems and economic losses [7,26]. Along with the upsurge of herb-drug combinations, inhibition of herbs towards drug-metabolic enzymes in HDIs has been raised as an important reason that limits clinical applications of herbs and drugs [17,27]. Currently, evaluating the inhibition of herbs toward UGT is recommended for safe use of herbs [16-18]. On the other hand, when a substrate is mainly metabolized through glucuronidation, significant increase of drug exposure via UGT inhibition has been reported (e.g., zidovudine and lamotrigine) $[6,28,29]$, suggesting that glucuronidation inhibition can be clinically significant. Moreover, when herbs and drugs are catalyzed through the same enzymatic pathway, UGTs involved in the metabolism of herbs have the potential to inhibit drug glucuronidation [18].

As shown in Table 1, sauchinone inhibited activities of UGTs in HLM, showing the following inhibition order: UGT2B7 $>>1 \mathrm{~A} 6>1 \mathrm{~A} 1>1 \mathrm{~A} 3$. There was negligible change in metabolic rate with increasing sauchinone concentrations up to $200 \mu \mathrm{M}$ (our unpublished data). This could be due to un-saturation of the enzyme at the incubation condition used in this study. To explore how UGTs interacted with their substrates and inhibitors, inhibition kinetic studies of sauchinone on UGT1A6 and 2B7 were performed. As shown in Figure 2, sauchinone inhibited UGT1A6 and 2B7 in non-competitive manners. Non-competitive inhibitions of sauchinone on UGT1A6 and 2B7 indicated that sauchinone might bind different sites of substrates. In other words, sauchinone might be able to reduce UGT1A6 and 2B7 activities by binding to allosteric site of UGT without interfering with the binding of a substrate to the active site of UGT.

Evaluating the inhibitory effect of herbs on UGTs in in vitro systems has been used to predict metabolic elimination of co-administered drugs, leading to changes in efficacy and toxicity $[9,30]$. However, in vitro results referring the inhibitory effects of herbs based on $\mathrm{IC}_{50}$ and $K_{\mathrm{i}}$ values are not sufficient to provide relevance to in vivo results especially at clinical levels. This is because more various metabolic pathways and other elimination pathways except metabolism (e.g., urinary excretion or biliary excretion) can be involved in HDIs in vivo [26,31,32]. For example, discrepancies of HDI for milk thistle, garlic extract, Panax quinquefolius, and Panax ginseng between in vitro and clinical results have been reported [18,31,33-35]. Investigation of HDIs in humans can accurately explain changes in efficacy or adverse reactions of co-administered drugs. However, initial evaluation of HDIs at a clinical level has been a concern due to serious problems with HDI. Hence, prediction of HDIs at preclinical level has been utilized as basic evidence to provide the potential of HDIs and its underlying mechanisms along with in vitro results $[18,26]$.

To predict the magnitude of HDI as described in drug-drug interactions, the most common equation for HDI prediction is based on in vivo AUC alternation of a drug as a substrate and in vitro $K_{\mathrm{i}}$ and in vivo concentration of herb as an inhibitor as previously reported [26,31,36]. Parameters used to explain in vivo and in vitro inhibition potency should dictate the likelihood of pharmacokinetic drug interactions as Equation (1)

$$
\frac{\mathrm{AUC}_{\mathrm{i}}}{\mathrm{AUC}_{0}}=1+\frac{[\mathrm{I}]}{K_{\mathrm{i}}}
$$

Assuming that a drug is a substrate and a herb is an inhibitor toward hepatic metabolic enzymes in $\mathrm{HDIs}$, the following terms are defined: $\mathrm{AUC}_{\mathrm{i}} / \mathrm{AUC}_{0}$ is the predicted ratio of in vivo exposure of a drug with a herb $\left(\mathrm{AUC}_{\mathrm{i}}\right)$ versus that in control situation (without a herb; $\left.\mathrm{AUC} \mathrm{C}_{0}\right),[\mathrm{I}]$ is the concentration of an herb in the liver (as an enzyme active site), and $K_{\mathrm{i}}$ is an inhibition constant of a herb. This calculation also assumes that metabolic enzyme contributes $100 \%$ of a drug metabolism. To determine whether metabolic inhibition in liver can occurs or not, the ratio of [I] to $K_{\mathrm{i}}$ is calculated because sufficient concentration of an inhibitor in the liver is a critical factor that causes metabolic inhibition. Occasionally, $\mathrm{C}_{\max }$ has been used instead of [I], assuming that systemic exposure and tissue exposure of an inhibitor are similar [37]. In this case, [I] represents the mean steady-state $C_{\max }$ following administration of the 
highest proposed clinical dose [26,36]. Unfortunately, sauchinone-drug interaction cannot be estimated in human levels at this time, because hepatic concentration or $C_{\max }$ of sauchinone in human has not been reported yet.

With such situation, pharmacokinetic changes of a drug metabolized via Ugt2b7 when co-administered with sauchinone were evaluated in mice. As shown in Figure 3, sauchinone inhibited Ugt2b7 > 1a9 > 1a6 in MLM. This result suggested that Ugt2b7 inhibition by sauchinone might affect UGT2B7-mediated metabolism of drugs such as zidovudine [32,38,39]. Among clinically relevant drug interactions involving UGTs, UGT2B7 is the most commonly implicated enzyme [40], contributing to glucuronidation of drugs and endogenous compounds (i.e., bile acids, fatty acids, and steroids) [41]. Zidovudine has an especially narrow therapeutic index. Slight alternation of zidovudine concentration or unexpected increase of zidovudine exposure by UGT2B7 inhibition can cause toxicity (e.g., bone marrow toxicity or genotoxicity) [39,42]. Thus, it is meaningful to predict the potential of sauchinone-zidovudine interaction through UGT2B7. To predict the inhibitory effect of sauchinone on UGT2B7-mediated zidovudine metabolism, the following values were adjusted in Equation (1): $\mathrm{AUC}_{\mathrm{i}} / \mathrm{AUC}$ of zidovudine was 1.52 from Table 2, $\mathrm{C}_{\max }$ of sauchinone in mice plasma after oral administration of $100 \mathrm{mg} / \mathrm{kg}$ sauchinone was $1.53 \mu \mathrm{M}$ [24] instead of [I], and $K_{\mathrm{i}}$ of sauchinone for Ugt2b7 in mouse liver microsomes was $3.34 \mu \mathrm{M}$ (our unpublished data). U.S. FDA (2012) recommends clinical evaluation of sensitive substrate if $\mathrm{AUC}_{\mathrm{i}} / \mathrm{AUC}$ of a substrate is above 1 . Also ' $0.1<[\mathrm{I}] / K_{\mathrm{i}}<1^{\prime}$ is considered to have median possibility of drug interaction based on [I] $/ K_{\mathrm{i}}$ standard [7]. Thus, 1.52 for $\mathrm{AUC}_{\mathrm{i}} / \mathrm{AUC}$ of zidovudine and 0.458 for $[\mathrm{I}] / K_{\mathrm{i}}$ indicated inhibitory effect of sauchinone on UGT2B7 involved zidovudine metabolism. Also the slower $C L$ and $\mathrm{CL}_{\mathrm{NR}}$ of zidovudine with sauchinone indicted that sauchinone inhibited metabolic clearance of zidovudine compared to those without sauchinone. Interestingly, except for the metabolism of zidovudine, other pharmacokinetic profiles of zidovudine were not changed by co-administration of sauchinone. Distribution and excretion of zidovudine were not affected by sauchinone, supported by comparable Vss, $\mathrm{t}_{1 / 2}, \mathrm{MRT}, \mathrm{Ae}_{0-24 \mathrm{~h}}$, and $\mathrm{GI}_{24} \mathrm{~h}$ of zidovudine between with and without sauchinone.

There are some limitations to our calculations. First, inhibition of sauchinone or zidovudine metabolites towards UGTs was not investigated. Glucuronidation, oxidation, methylation, and dehydrogenation are involved in sauchionone metabolism [24]. Glucuronindation and reduction contribute to zidovudine metabolism [43]. UGT-mediated metabolic pathway of sauchinone or zidovudine can cause auto-inhibition in the process of their own metabolism as incubation time goes on. In other words, metabolites of sauchinone or zidovudine can inhibit UGTs. Similarly, it has been reported that gemfibrozil inhibits repaglinide glucuronidation via UGT1A1, because gemfibrozil and gemfibrozil glucuronide (a main metabolite of gemfibrozil) inhibit UGT1A1 together [30]. Second, in vitro and in vivo differences both explain pharmacokinetic interactions. Substrate, inhibitor, and glucuronidated metabolite(s) can be eliminated in in vivo. However, this does not occur in an in vitro microsomal incubation system. When the accumulation of metabolites happens in the reaction process, it inhibits enzyme activity [6]. Also, several other factors such as protein binding, active uptake, and efflux transporters in tissues may affect the estimation of unbound drug concentrations at interaction site. In this respect, in vitro data tend to underestimate inhibition of drug glucuronidation compared to in vivo [44]. Moreover, renal clearance and cytochrome P450-mediated metabolism can be altered by sauchinone in vivo, which can affect the elimination route of zidovudine [43]. In addition, individual difference in intestinal bacteria might influence sauchinone absorption in the blood that might influence in vivo extrapolation results [43]. Thus, extrapolation from in vitro data to in vivo drug interaction should be taken with caution. 


\section{Materials and Methods}

\subsection{Chemicals and Reagents}

Sauchinone was extracted and purified according to a method reported previously [20]. The purity of sauchinone was determined to be over $98 \%$ by using Waters Acquity ${ }^{\mathrm{TM}}$ Ultra Performance LC system (Waters Corp., Milford, MA, USA) equipped with an ACQUITY UPLC ${ }^{\circledR}$ BEH C18 column $(2.1 \times 150 \mathrm{~mm}, 1.7 \mu \mathrm{m})$ and detailed information for structure elucidation and purity experiment were provided in supplementary data. Pooled human liver microsomes from a mixed pool of 50 donors (HLMs; BD Ultra Pool HLM 50, cat. 452156) and human cDNA-expressed UGT enzymes (UGT1A6 and 2B7) were purchased from Corning Life Sciences (Woburn, MA, USA). Alamethicin, $\beta$-estradiol, $\beta$-estradiol-3-glucuronide, chenodeoxy cholic acid, lithocholic acid, chrysin, efavirenz, niflumic acid, 1-naphthol, serotonin hydrochloride, trifluoperazine dihydrochloride, zidovudine, chenodeoxycholic acid, lithocholic acid, the reduced form of $\beta$-nicotinamide adenine dinucleotide phosphate (NADPH; as a tetrasodium salt), and uridine $5^{\prime}$-diphosphoglucuronic acid trisodium salt (UDPGA) were purchased from Sigma-Aldrich (St. Louis, MO, USA). Midazolam and propofol were supplied from Korea Ministry of Food and Drug Safety (Chung-cheong-buk-do, Republic of Korea). Hecogenin, propofol-O-glucuronide, serotonin-O-glucuronide, trifluoperazine- $N$-glucuronide, and zidovudine-5'-glucuronide were purchased from Tokyo Chemical Industry Co. (Tokyo, Japan). Chenodeoxy cholic acid-24-acyl- $\beta$-D-glucuronide was purchased from Carbosynth (Berkshire, UK). Carbamazepine [an internal standard (IS) of ultra-performance liquid chromatography-tandem mass spectrometry (UPLC-MS/MS)] was purchased from Wako Co. (Tokyo, Japan). All other chemicals and reagents used were of analytical grade.

\subsection{Animals}

To conduct in vitro (mice liver microsomal study) and in vivo (pharmacokinetic study) investigations using mice, animal studies were approved by the Institute of Laboratory Animal Resources of Dongguk University, Seoul, Republic of Korea (IACUC-2016-046). Five-week-old (20-25 g) male Institute of Cancer Research mice were purchased from the Charles River Company of Korea (Orient, Seoul, Republic of Korea). Upon arrival, mice were randomized and housed at five mice per cage under strictly controlled environmental conditions $\left(22-25^{\circ} \mathrm{C}\right.$ and $48-52 \%$ relative humidity) with a $12 \mathrm{~h}$ light/dark cycle at 150-300 lx luminous intensity. All mice were provided food and water and were maintained during this study.

\subsection{Inhibitory Effects of Sauchinone on UGT Activities}

Inhibitory effects of sauchinone on UGT1A1, 1A3, 1A4, 1A6, 1A9, and 2B7 activities were evaluated using HLMs. Formations of $\beta$-estradiol-3-glucuronide, chenodeoxy cholic acid-24-acyl- $\beta$-D-glucuronide, trifluoperazine- $N$-glucuronide, serotonin-O-glucuronide, propofol-O-glucuronide, and zidovudine-5' glucuronide represented glucuronidation efficacy of UGT1A1, 1A3, 1A4, 1A6, 1A9, and 2B7, respectively, in HLMs. As UGT selective substrates, $\beta$-estradiol, chenodeoxy cholic acid, propofol, and zidovudine were dissolved in methanol, whereas trifluoperazine and serotonin were dissolved in $50 \%$ ethanol. These dissolved substrate solutions were serially diluted to required concentrations as a UGT cocktail set containing $\beta$-estradiol, chenodeoxy cholic acid, trifluoperazine, serotonin, propofol, and zidovudine. Spiked volume of UGT cocktail set was $1 \%(v / v)$ of total volume of mixture. Concentrations of UGT selective substrates were used close to their reported $K_{m}$ values [9]: $10 \mu \mathrm{M} \beta$-estradiol, $15 \mu \mathrm{M}$ chenodeoxy cholic acid, $40 \mu \mathrm{M}$ trifluoperazine, $40 \mu \mathrm{M}$ serotonin, $100 \mu \mathrm{M}$ propofol, and $100 \mu \mathrm{M}$ zidovudine as substrate of UGT1A1, 1A3, 1A4, 1A6, 1A9, and 2B7, respectively. The reaction mixture containing $0.25 \mathrm{mg} / \mathrm{mL}$ protein of HLM, $100 \mathrm{mM}$ Tris buffer ( $\mathrm{pH} 7.6$ ), $5 \mathrm{mM} \mathrm{MgCl} 2,25 \mu \mathrm{g} / \mathrm{mL}$ of alamethicin, the UGT selective substrates' cocktail set and various concentrations of sauchinone $(0-200 \mu \mathrm{M})$ or a well-known inhibitor of each UGT isoform were pre-incubated for $30 \mathrm{~min}$ on ice to allow formation of alamethicin pores. The reaction was initiated by adding $5 \mathrm{mM}$ UDPGA to a final 
volume of $150 \mu \mathrm{L}$ and incubated at $37^{\circ} \mathrm{C}$ for 15 or $60 \mathrm{~min}$ in a thermomixer at $500 \mathrm{rpm}$. Each reaction was stopped by adding $150 \mu \mathrm{L}$ of ice-cold methanol containing $50 \mathrm{ng} / \mathrm{mL}$ IS. These mixtures were then centrifuged $\left(12,000 \mathrm{rpm}\right.$ for $10 \mathrm{~min}$ at $\left.4{ }^{\circ} \mathrm{C}\right)$ and $5 \mu \mathrm{L}$ of the supernatant was injected into a UPLC-MS/MS system. As positive controls, well-known inhibitors such as chrysin, lithocholic acid, hecogenin, 1-naphthol, niflumic acid, and efavirenz for UGT1A1, 1A3, 1A4, 1A6, 1A9, and 2B7, respectively, were used to validate the experiments. Their $\mathrm{IC}_{50}$ values were compared to that of sauchinone. All inhibitors were dissolved in methanol (except for hecogenin, which was dissolved in dimethyl sulfoxide) and serially diluted to the required concentrations using the same solutions. The final concentration of organic solvent of inhibitors was $1 \%(v / v)$. All studies were performed in triplicate and mean values were used in the analysis. The half maximal inhibition constant $\left(\mathrm{IC}_{50}\right)$ of sauchinone on UGT isoforms was estimated using GraphPad program.

\subsection{Inhibition Constant $\left(K_{i}\right)$ of Sauchinone on UGT1A6 and 2B7-Mediated Glucuronidation Activities}

Based on $I C_{50}$ values, $K_{i}$ values of sauchinone for UGT1A6 and $2 \mathrm{~B} 7$ were determined. Concentrations of $0-200 \mu \mathrm{M}$ of sauchinone were used. Other procedures were similar to those mentioned above in the study of reversible inhibitory effects of sauchinone. Inhibitory characteristics of sauchinone were initially estimated by nonlinear least squares regression analysis and $K_{i}$ values were determined by Dixon plots [45].

\subsection{Inhibitory Effects of Sauchinone on UGT Activities Using MLM}

Inhibitory effects of sauchinone on UGT1A1, 1A3, 1A6, 1A9, and 2B7 activities were evaluated using MLM. Mice were sacrificed and then livers were removed and rinsed with saline. After weighing the livers, they were homogenized with a four-fold volume of ice-cold homogenizing buffer $(0.154 \mathrm{M} \mathrm{KCl}, 50 \mathrm{mM}$ Tris-base, $1 \mathrm{mM}$ EDTA, $\mathrm{pH} 7.4)$. After centrifugation for $35 \mathrm{~min}$ at $9000 \times g$ and $4{ }^{\circ} \mathrm{C}$, the supernatants were centrifuged for $95 \mathrm{~min}$ at $100,000 \times \mathrm{g}$ and at $4{ }^{\circ} \mathrm{C}$. The supernatants were discarded and the pellets were homogenized again with ice-cold homogenizing buffer. These aliquots were stored at $-80^{\circ} \mathrm{C}$. The subsequent process to evaluate the inhibitory effects of sauchinone on UGT activities in MLM was the same as those using HLM.

\subsection{UPLC-MS/MS Analysis for Metabolites of UGTs Substrates}

Metabolites of UGT-selective substrates were detected using an Waters UPLC-XEVO TQ system (Waters Corporation, Milford, MA, USA) in multiple reaction monitoring (MRM) mode with an ESI interface for positive ions $\left([\mathrm{M}+\mathrm{H}]^{+}\right)$and negative ions $\left([\mathrm{M}-\mathrm{H}]^{-}\right)$. Separation was performed on a reversed-phase $\mathrm{C}_{18}$ column $(\mathrm{BEH}, 1.7 \times 100 \mathrm{~mm}$ i.d., $2.1 \mu \mathrm{m}$ particle size; Waters, Dublin, Ireland) maintained at $30{ }^{\circ} \mathrm{C}$. The mobile phase consisted of water containing $0.1 \%$ formic acid (A) and acetonitrile (B) at a ratio of 85:15 (v/v) for $3 \mathrm{~min}$ and gradually changed to 10:90 (v/v) for $5.5 \mathrm{~min}$. This composition was maintained until $6.5 \mathrm{~min}$ and then back to initially composition at a flow rate of $0.3 \mathrm{~mL} / \mathrm{min}$. The total run time was $9 \mathrm{~min}$.

Turbo ion-spray interface was operated in positive ion mode at an ion capillary voltage of $2500 \mathrm{~V}$ and a temperature of $350^{\circ} \mathrm{C}$. Operating conditions (gas flow, $650 \mathrm{~L} / \mathrm{h}$; cone gas flow, $10 \mathrm{~L} / \mathrm{h}$ ) were optimized by flow injection of a mixture of all analytes. The $m / z$ value (CE value) for each metabolite of UGT-selective substrate was as follows: $\beta$-estradiol-3-glucuronide $(m / z 446.93 \rightarrow 270.90$, $-40 \mathrm{~V}$ of $\mathrm{CE})$, chenodeoxy cholic acid-24-acyl- $\beta$-D-glucuronide $(\mathrm{m} / z 567.33 \rightarrow 567.33,-10 \mathrm{~V})$, trifluoperazine- $N$-glucuronide $(\mathrm{m} / \mathrm{z} 584.23 \rightarrow 408.20,25 \mathrm{~V})$, serotonin-O-glucuronide $(\mathrm{m} / \mathrm{z} 353.13 \rightarrow 177.10$, $10 \mathrm{~V})$, propofol-O-glucuronide $(\mathrm{m} / \mathrm{z} 353.13 \rightarrow 177.10,-19 \mathrm{~V})$, and zidovudine- $5^{\prime}$-glucuronide $(\mathrm{m} / \mathrm{z}$ $442.13 \rightarrow 125.0,-26 \mathrm{~V})$.

\subsection{Data Analysis}

UGT-mediated activities in the presence of sauchinone as an inhibitor were expressed as percentages of corresponding control values (in absence of sauchinone). From percentages of control 
activity versus inhibitor concentrations, a sigmoid shaped curve was fitted to the data and $\mathrm{IC}_{50}$ as an enzyme inhibition parameter was calculated by fitting the Hill equation to the data using GraphPad Prism 5 (GraphPad Software Inc., San Diego, CA, USA).

\subsection{Pharmacokinetic Study of Zidovudine with or without Sauchinone}

To investigate the inhibitory effects of sauchinone on UGT2B7-mediated metabolism, zidovudine was chosen as an example drug mainly metabolized via UGT2B7 [46]. Surgical procedures of mice were conducted under tiletamine $\mathrm{HCl}$ and zolazepam $\mathrm{HCl}$ anesthesia by intramuscular injection. Jugular vein (for zidovudine administration) and carotid artery (for blood sampling) cannulations were carried out using catheters (BASi, West Lafayette, IN, USA). Five hours after surgery, drug administration and blood sampling were allowed [24]. Thirty minutes after oral administration of $100 \mathrm{mg} / \mathrm{kg}$ sauchinone, $15 \mathrm{mg} / \mathrm{kg}$ of zidovudine was administered intravenously to mice. Blood samples were collected via the carotid artery at $0,1,5,15,30,60,120,240,360$, and $480 \mathrm{~min}$ after administration of zidovudine. A $10-\mu \mathrm{L}$ of blood was collected into a micro-vial with $50-\mu \mathrm{L}$ of $12.5 \mathrm{units} / \mathrm{mL}$ heparinized saline using micro-sampling system. After centrifugation of each micro-vial, a $50-\mu \mathrm{L}$ of plasma with heparinized-saline was collected from the supernatant, which was analyzed by UPLC-MS/MS. Also, at the end of $24 \mathrm{~h}$, each metabolic cage was flushed with $5 \mathrm{~mL}$ of distilled water and urine samples were collected $\left(\mathrm{Ae}_{0-24 \mathrm{~h}}\right)$. The gastrointestinal tract was cut and extracted with $20 \mathrm{~mL}$ of methanol, of which supernatant was collected $\left(\mathrm{GI}_{24} \mathrm{~h}\right)$. Urine and GI samples were then analyzed using UPLC-MS/MS.

After the analysis of zidovudine concentrations in plasma by UPLC-MS/MS, pharmacokinetic parameters were calculated as follows. The area under the plasma concentration-time curve from time zero to the last measured time to infinity or last sampling time (480 min) (AUC or $\mathrm{AUC}_{480 \mathrm{~min}}$ ) was calculated using the trapezoidal rule method. Standard methods [47] were used to calculate pharmacokinetic parameters using a non-compartmental analysis (WinNonlin 2.1; Pharmasight Corp., Mountain View, CA, USA). Peak plasma concentration $\left(C_{\max }\right)$ and time to reach $C_{\max }\left(T_{\max }\right)$ were read reversibly from the extrapolated data.

\section{Conclusions}

The present study investigated the inhibitory potential of sauchinone towards UGTs to cause drug interactions for the first time. In detail, sauchinone inhibited UGT activities in the following order: UGT2B7 > 1A6 > 1A1. It noncompetitively inhibited UGT1A6 and 2B7 activities in vitro. Sauchinone also increased systemic exposure of zidovudine, a substrate of UGT2B7, through UGT2B7 inhibition in vivo mice. All these results provide an early warning for the combination between sauchinone and drugs mainly metabolized by UGT2B7. Due to various contributions of UGT isoforms toward drug metabolism as well as species and individual differences, further clinical investigations should be considered.

Supplementary Materials: Supplementary materials are available online.

Acknowledgments: This study was supported by a grant (NRF-2016R1C1B2010849) from the National Research Foundation of Korea (NRF) grant funded by the Korea government (MSIT).

Author Contributions: Byoung Hoon You and Eun Chae Gong conducted experiments; Young Hee Choi designed experiments and wrote manuscript.

Conflicts of Interest: The authors declare no conflicts of interest.

\section{References}

1. Qiu, J. China Plans to Modernize Traditional Medicine. Nature 2007, 446, 590-591. [CrossRef] [PubMed]

2. Zhang, L.; Reynods, K.S.; Zhao, P.; Huang, S.M. Drug Interactions Evaluation: An Integrated Part of Risk Assessment of Therapeutics. Toxicol. Appl. Pharmacol. 2010, 243, 134-145. [CrossRef] [PubMed] 
3. Li, L.; Hu, H.; Xu, S.; Zhou, Q.; Zeng, S. Roles of UDP-Glucuronosyltransferases in Phytochemical Metabolisms of Herbal Medicines and Associated Herb-Drug Interactions. Curr. Drug Metab. 2012, 13, 615-623. [CrossRef] [PubMed]

4. Rastogi, H.; Jana, S. Evaluation of Inhibitory Effects of Caffeic Acid and Quercetin on Human Liver Cytochrome p450 Activities. Phytother. Res. 2014, 28, 1873-1878. [CrossRef] [PubMed]

5. Walsky, R.L.; Bauman, J.N.; Bourcier, K.; Giddens, G.; Lapham, K.; Negahban, A.; Ryder, T.F.; Obach, R.S.; Hyland, R.; Goosen, T.C. Optimized Assays for Human UDP-Glucuronosyltransferase (UGT) Activities: Altered Alamethicin Concentration and Utility to Screen for UGT Inhibitors. Drug Metab. Dispos. 2012, 40, 1051-1065. [CrossRef] [PubMed]

6. Kiang, T.K.; Ensom, M.H.; Chang, T.K. UDP-Glucuronosyltransferases and Clinical Drug-Drug Interactions. Pharmacol. Ther. 2005, 106, 97-132. [CrossRef] [PubMed]

7. Ran, R.; Zhang, C.; Li, R.; Chen, B.; Zhang, W.; Zhao, Z.; Fu, Z.; Du, Z.; Du, X.; Yang, X.; et al. Evaluation and Comparison of the Inhibition Effect of Astragaloside IV and Aglycone Cycloastragenol on Various UDP-Glucuronosyltransferase (UGT) Isoforms. Molecules 2016, 21, E1616. [CrossRef] [PubMed]

8. Nagar, S.; Remmel, R.P. Uridine Diphosphoglucuronosyltransferase Pharmacogenetics and Cancer. Oncogene 2006, 25, 1659-1672. [CrossRef] [PubMed]

9. Zhang, X.S.; Zhao, Z.Q.; Qin, Z.S.; Wu, K.; Xia, T.F.; Pang, L.Q. Herb-Drug Interaction Between Irinotecan and Psoralidin-Containing Herbs. Eur. J. Drug Metab. Pharmacokinet. 2015, 40, 481-484. [CrossRef] [PubMed]

10. Prueksaritanont, T.; Zhao, J.J.; Ma, B.; Roadcap, B.A.; Tang, C.; Qiu, Y.; Liu, L.; Lin, J.H.; Pearson, P.G.; Baillie, T.A. Mechanistic Studies on Metabolic Interactions Between Gemfibrozil and Statins. J. Pharmacol. Exp. Ther. 2002, 301, 1042-1051. [CrossRef] [PubMed]

11. Wang, Y.C.; Yang, H.T.; Kong, L.T.; Yu, F.X. In vitro Evidence of Baicalein's Inhibition of the Metabolism of Zidovudine (AZT). Afr. Health Sci. 2014, 14, 173-177. [PubMed]

12. Sakakibara, Y.; Katoh, M.; Kondo, Y.; Nadai, M. Effects of Phenobarbital on Expression of UDP-Glucuronosyltransferase $1 \mathrm{a} 6$ and 1a7 in Rat Brain. Drug Metab. Dispos. 2016, 44, 370-377. [CrossRef] [PubMed]

13. Mutlib, A.E.; Goosen, T.C.; Bauman, J.N.; Williams, J.A.; Kulkarni, S.; Kostrubsky, S. Kinetics of Acetaminophen Glucuronidation by UDP-Glucuronosyltransferases 1A1, 1A6, 1A9 and 2B15. Potential Implications in Acetaminophen-Induced Hepatotoxicity. Chem. Res. Toxicol. 2006, 19, 701-709. [CrossRef] [PubMed]

14. Kasichayanula, S.; Liu, X.; Griffen, S.C.; Lacreta, F.P.; Boulton, D.W. Effects of Rifampin and Mefenamic Acid on the Pharmacokinetics and Pharmacodynamics of Dapagliflozin. Diabetes Obes. Metab. 2013, 15, 280-283. [CrossRef] [PubMed]

15. Lertora, J.J.; Rege, A.B.; Greenspan, D.L.; Akula, S.; George, W.J.; Hyslop, N.E., Jr.; Agrawal, K.C. Pharmacokinetic Interaction Between Zidovudine and Valproic Acid in Patients Infected with Human Immunodeficiency Virus. Clin. Pharmacol. Ther. 1994, 56, 272-278. [CrossRef] [PubMed]

16. FDA, Center for Drug Evaluation and Research, Guideline for Industry. Drug Interaction Studies-Study Design, Data Analysis, Implication for Dosing, and Labeling Recommendations; Food and Drug Administration: Rockville, MD, USA, 2012.

17. Thelingwani, R.; Masimirembwa, C. Evaluation of Herbal Medicines: Value Addition to Traditional Medicines through Metabolism, Pharmacokinetic and Safety Studies. Curr. Drug Metab. 2014, 15, 942-952. [CrossRef] [PubMed]

18. Mohamed, M.E.; Frye, R.F. Effects of Herbal Supplements on Drug Glucuronidation. Review of clinical, animal, and in vitro studies. Planta Med. 2011, 77, 311-321. [CrossRef] [PubMed]

19. Meng, X.; Kim, I.; Jeong, Y.J.; Cho, Y.M.; Kang, S.C. Anti-Ifflammatory Effects of Saururus chinensis Aerial Parts in Murine Macrophages via Induction of Heme Oxygenase-1. Exp. Biol. Med. (Marywood) 2016, 241, 396-408. [CrossRef] [PubMed]

20. Sung, S.H.; Kim, Y.C. Hepatoprotective Diastereomeric Lignans from Saururus chinensis Herbs. J. Nat. Prod. 2000, 63, 1019-1021. [CrossRef] [PubMed]

21. Chung, B.S.; Shin, M.G. Dictionary of Korean Folk Medicine; Young Lim Sa: Seoul, Korea, 1990; pp. $813-814$.

22. Jeong, H.J.; Koo, B.S.; Kang, T.H.; Shin, H.M.; Jung, S.H. Inhibitory Effects of Saururus chinensis and its Components on Stomach Cancer Cells. Phytomedicine 2015, 22, 256-261. [CrossRef] [PubMed] 
23. Lee, C.S.; Won, C.; Yoo, H.; Yi, E.H.; Cho, Y.; Maeng, J.W.; Sung, S.H.; Ye, S.K.; Chung, M.H. Inhibition of Double-Stranded RNA-Induced Inducible Nitric Oxide Synthase Expression by Fraxinellone and Sauchinone in Murine Microglia. Biol. Pharm. Bull. 2009, 32, 1870-1874. [CrossRef] [PubMed]

24. Kim, Y.J.; Han, S.Y.; Seo, J.S.; Chin, Y.W.; Choi, Y.H. Pharmacokinetics, Tissue Distribution, and Tentative Metabolite Identification of Sauchinone in Mice by Microsampling and HPLC-MS/MS Methods. Biol. Pharm. Bull. 2015, 38, 218-227. [CrossRef] [PubMed]

25. Butterworth, P.J. The use of Dixon Plots to Study Enzyme Inhibition. Biochem. Biophys. Acta 1972, 289, 251-253. [CrossRef]

26. Sun, D.; Zhang, C.Z.; Ran, R.X.; Cao, Y.F.; Du, Z.; Fu, Z.W.; Huang, C.T.; Zhao, Z.Y.; Zhang, W.H.; Fang, Z.Z. In Vitro Comparative Study of the Inhibitory Effects of Mangiferin and Its Aglycone Norathyriol towards UDP-Glucuronosyl Transferase (UGT) Isoforms. Molecules 2017, 22, E1008. [CrossRef] [PubMed]

27. Gardiner, P.; Phillips, R.; Shaughnessy, A.F. Herbal and Dietary Supplement—Drug Interactions in Patients with Chronic Illnesses. Am. Fam. Physician 2008, 77, 73-78. [PubMed]

28. Lee, B.L.; Tauber, M.G.; Sadler, B.; Goldstein, D.; Chambers, H.F. Atovaquone Inhibits the Glucuronidation and Increases the Plasma Concentrations of Zidovudine. Clin. Pharmacol. Ther. 1996, 59, 14-21. [CrossRef]

29. Sahai, J.; Gallicano, K.; Pakuts, A.; Cameron, D.W. Effect of Fluconazole on Zidovudine Pharmacokinetics in Patients Infected with Human Immunodeficiency Virus. J. Infect. Dis. 1994, 169, 1103-1107. [CrossRef] [PubMed]

30. Gan, J.; Chen, W.; Shen, H.; Gao, L.; Hong, Y.; Tian, Y.; Li, W.; Zhang, Y.; Tang, Y.; Zhang, H.; et al. Repaglinide-Gemfibrozil Drug Interaction: Inhibition of Repaglinide Glucuronidation as a Potential Additional Contributing Mechanism. Br. J. Clin. Pharmacol. 2010, 70, 870-880. [CrossRef] [PubMed]

31. He, Y.J.; Fang, Z.Z.; Ge, G.B.; Jiang, P.; Jin, H.Z.; Zhang, W.D.; Yang, L. The Inhibitory Effect of 20(S)-Protopanaxatriol (ppt) Towards UGT1A1 and UGT2B7. Phytother. Res. 2013, 27, 628-632. [CrossRef] [PubMed]

32. Sun, H.; Zhang, T.; Wu, Z.; Wu, B. Warfarin is an Effective Modifier of Multiple UDP-Glucuronosyltransferase Enzymes: Evaluation of its Potential to Alter the Pharmacokinetics of Zidovudine. J. Pham. Sci. 2015, 104, 244-256. [CrossRef] [PubMed]

33. Gwilt, P.R.; Lear, C.L.; Tempero, M.A.; Birt, D.D.; Grandjean, A.C.; Ruddon, R.W.; Nagel, D.L. The Effect of Garlic Extract on Human Metabolism of Acetaminophen. Cancer Epidemiol. Biomark. Prev. 1994, 3, 155-160.

34. Lee, L.S.; Wise, S.D.; Chan, C.; Parsons, T.L.; Flexner, C.; Lietman, P.S. Possible Differential Induction of Phase 2 Enzyme and Antioxidant Pathways by American Ginseng, Panax quinquefolius. J. Clin. Pharmacol. 2008, 48, 599-609. [CrossRef] [PubMed]

35. Van Erp, N.P.; Baker, S.D.; Zhao, M.; Rudek, M.A.; Guchelaar, H.J.; Nortier, J.W.; Sparreboom, A.; Gelderblom, H. Effect of Milk Thistle (Silybum marianum) on the Pharmacokinetics of Irinotecan. Clin. Cancer Res. 2005, 11, 7800-7806. [CrossRef] [PubMed]

36. Goey, A.K.; Mooiman, K.D.; Beijnen, J.H.; Schellens, J.H.; Meijerman, I. Relevance of In vitro and Clinical Data for Predicting CYP3A4-Mediated Herb-Drug Interactions in Cancer Patients. Cancer Treat. Rev. 2013, 39, 773-783. [CrossRef] [PubMed]

37. Filppula, A.M.; Neuvonen, P.J.; Backman, J.T. In vitro Assessment of Time-Dependent Inhibitory Effects on CYP2C8 and CYP3A Activity by Fourteen Protein Kinase Inhibitors. Drug Metab. Dispos. 2014, 42, 1202-1209. [CrossRef] [PubMed]

38. Court, M.H.; Krishnaswamy, S.; Hao, Q.; Duan, S.X.; Patten, C.J.; Von Moltke, L.L.; Greenblatt, D.J. Evaluation of $3^{\prime}$-azido-3'-deoxythymidine, Morphine, and Codeine as Probe Substrates for UDP-Glucuronosyltransferase 2B7 (UGT2B7) in Human Liver Microsomes: Specificity and Influence of the UGT2B7² Polymorphism. Drug Metab. Dispos. 2003, 31, 1125-1133. [CrossRef] [PubMed]

39. Wang, H.; Yan, T.; Xie, Y.; Zhao, M.; Che, Y.; Zhang, J.; Liu, H.; Cao, L.; Cheng, X.; Xie, Y.; et al. Mechanism-Based Inhibitory and Peroxisome Proliferator-Activated Receptor $\alpha$-Dependent Modulating Effects of Silybin on Principal Hepatic Drug-Metabolizing Enzymes. Drug Metab. Dispos. 2015, 43, 444-454. [CrossRef] [PubMed]

40. Rowland, A.; Miners, J.O.; Mackenzie, P.I. The UDP-Glucuronosyltransferases: Their Role in Drug Metabolism and Detoxification. Int. J. Biochem. Cell Biol. 2013, 45, 1121-1132. [CrossRef] [PubMed]

41. Oda, S.; Fukami, T.; Yokoi, T.; Nakajima, M. A Comprehensive Review of UDP-Glucuronosyltransferase and Esterases for Drug Development. Drug Metab. Pharmacokinet. 2015, 30, 30-51. [CrossRef] [PubMed] 
42. Kumar, P.; Lakshmi, Y.S.; C, B.; Golla, K.; Kondapi, A.K. Improved Safety, Bioavailability and Pharmacokinetics of Zidovudine through Lactoferrin Nanoparticles during Oral Administration in Rats. PLoS ONE 2015, 10, e0140399. [CrossRef] [PubMed]

43. Zhou, X.J.; Squires, K.; Pan-Zhou, X.R.; Bernhard, S.; Agrofoglio, L.; Kirk, M.; Duchin, K.L.; Sommadossi, J.P. Phase I Dose-Escalation Pharmacokinetics of AZT-P-ddI (IVX-E-59) in Patients with Human Immunodeficiency Virus. J. Clin. Pharmacol. 1997, 37, 201-213. [CrossRef] [PubMed]

44. Uchaipichat, V.; Winner, L.K.; Macjenzie, P.I.; Elliot, D.J.; Williams, J.A.; Miners, J.O. Quantitative Prediction of In vivo Inhibitory Interactions Involving Glucuronidated Drugs from In vitro Data: The Effect of the Fluconazole on Zidovudine Glucuronidation. Br. J. Clin. Pharmacol. 2006, 61, 427-439. [CrossRef] [PubMed]

45. Segel, I.H. Enzyme Kinetics: Behavior and Analysis of Rapid Equilibrium and Steady State Systems; Wiley: New York, NY, USA, 1975.

46. Giri, N.; Shaik, N.; Pan, G.; Terasaki, T.; Mukai, C.; Kitagaki, S.; Miyakoshi, N.; Elmquist, W.F. Investigation of the Role of Breast Cancer Resistance Protin (Bcrp/Abcg2) on Pharmacokinetics and Central Nervous System Penetration of Abacavir and Zidovudine in the Mouse. Drug Metab. Dispos. 2008, 36, 1476-1484. [CrossRef] [PubMed]

47. Perrier, D.; Gibaldi, M. General Derivation of the Equation for Time to Reach a Certain Fraction of Steady State. J. Pharm. Sci. 1982, 71, 474-475. [CrossRef] [PubMed]

Sample Availability: Samples of the compounds are not available from the authors. 